\title{
Therapeutic Influence of Exosomes Derived from Non-heat versus Heat Shocked Stem Cells on Experimentally Induced Myocardial Infarction in Adult Male Albino Rats
}

Original Article

\author{
Marwa Mohamed Yousry and Abeer Ibraheem Omar
}

Department of Histology, Faculty of Medicine, Cairo University, Cairo, Egypt

\begin{abstract}
Background: Worldwide, myocardial infarction (MI) is considered as a principal cause of mortality. It results in death of the cardiac myocytes and declining of the cardiac functions. Exosomes of the bone marrow mesenchymal stem cells (BMMSCs) are cell-free, nano-sized extracellular vesicles that have the same reparative potentiality of the stem cells. Heat shock is one of the stresses that increase the production of heat shock proteins in the stem cells augmenting their survival capabilities.

Aim of the Work: The current study aimed at assessing and comparing the therapeutic potentiality of exosomes derived from the non-heat and the heat shocked BMMSCs $\left({ }^{\text {non-HS}}\right.$ BMMSCs-EXOs and ${ }^{\mathrm{HS}}$ BMMSCs-EXOs) on experimentally induced MI (acute \& chronic stages) with underlining the probable explanation for that difference.

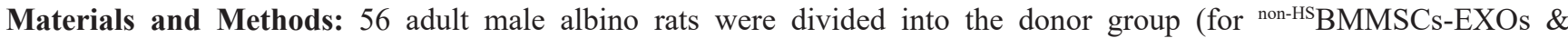
${ }^{\mathrm{HS}}$ BMMSCs-EXOs preparation) and the experimental groups (control, MI, MI- ${ }^{\text {non-HS}}$ BMMSCs-EXOs \& MI- ${ }^{\mathrm{HS}} \mathrm{BMMSCs}-$ EXOs). Four control rats with two rats from each MI- ${ }^{\text {non-HS}}$ BMMSCs-EXOs \& MI- ${ }^{\text {Hs }}$ BMMSCs-EXOs groups were sacrificed 1 day following MI to confirm BMMSCs-EXOs homing while other rats were sacrificed after $3 \& 28$ days. Serological, biochemical, histological and morphometric studies were done.

Results: The acute stage of MI revealed degenerative and inflammatory features whereas the chronic stage demonstrated marked fibrotic changes. Such changes were regressed in MI- ${ }^{\text {non-HS}}$ BMMSCs-EXOs \& MI- ${ }^{\mathrm{HS}}$ BMMSCs-EXOs groups except that of MI- ${ }^{\text {non-HS}}$ BMMSCs-EXOs sacrificed after 28 days.

Conclusion: Both ${ }^{\text {non-HS} B M M S C s-E X O s ~ a n d ~}{ }^{\mathrm{HS}}$ BMMSCs-EXOs had therapeutic capabilities in the acute stage of MI which was more evident with ${ }^{\mathrm{HS}} \mathrm{BMMSCs-EXOs.} \mathrm{In} \mathrm{the} \mathrm{chronic} \mathrm{stage,}{ }^{\text {non-HS}} \mathrm{BMMSCs-EXOs} \mathrm{exhibited} \mathrm{non-curative} \mathrm{effect} \mathrm{despite}$ the perfect effect of ${ }^{\mathrm{HS}} \mathrm{BMMSCs}-\mathrm{EXOs}$.
\end{abstract}

Received: 21 April 2020, Accepted: 03 May 2020

Key Words: Exosomes, heat shock factor 1, heat shock protein 70, microRNA-34a, myocardial infarction.

Corresponding Author: Marwa Mohamed Yousry, MD, Department of Histology, Faculty of Medicine, Cairo University, Egypt, Tel.: +20 1006763862, E-mail: marwa_yousry209@yahoo.com

ISSN: 1110-0559, Vol. 44, No.1

\section{INTRODUCTION}

Myocardial infarction, also called heart attack, is a focus of acute cardiac muscle cell death occurred as a sequel of reduced cardiac blood supply. It may result in cardiogenic shock and cardiac arrest ${ }^{[1]}$. Worldwide, its incidence is increased progressively, about $15 \times 10^{6}$ cases are recorded every year ${ }^{[2]}$. Epidemiologically, it was reported that most of the cases of MI ensued from coronary artery obstruction that might occur as a result of high blood pressure, high cholesterol, diabetes or smoking ${ }^{[3]}$. Myocardial infarction is associated with consequent great morbidity and mortality rates $^{[1]}$. This is not only due to the lesion itself but also due to the aggressive management interferences used in its treatment such as percutaneous coronary intervention $(\mathrm{PCI})$ and coronary artery bypass graft $(\mathrm{CABG})^{[4]}$. So, there is a crucial necessity to achieve long term therapy that is safer and more appropriate.

Mesenchymal stem cells (MSCs) have been found to retain obvious therapeutic potentiality in many different pathologies $^{[5]}$ which has been extended to cure cerebral ischemia $^{[6]}$. Such therapeutic capabilities of MSCs are based on their unique features as self-renewing, proliferating, multipotent differentiating and immunomodulatory properties $^{[5]}$.

In the case of MI, the use of stem cells showed limited improvement of the cardiac functions and infarct size where they undergo enormous cell death due to tissue hypoxia. It was stated that 2 and $18 \mathrm{~h}$ after stem cells transplantation, only $5 \%$ and $1 \%$ of the stem cells could be spotted in the myocardium, respectively ${ }^{[7]}$. Moreover, the stem cells recruitment to the ischemic myocardium aroused by the interaction between injured myocytes' stromal cellderived factor-1 (SDF-1) and its receptor CXC chemokine receptor 4 (CXCR4) was dampened after 3 days of MI This occurs since SDF-1 release is peaked 1-3 days then dropped to its basal level ${ }^{[8]}$. These hindrances in addition to the other potential threats of immune rejection and tumour development restrict the clinical use of stem cells in MI. 
Recently, MSCs have been documented to function through secretion of trophic factors (cytokines, chemokines, mRNAs, microRNAs and growth factors) that act on adjacent cells via a paracrine mechanism. These trophic factors are produced by MSCs as extracellular vesicles (EVs), namely MSCs secretomes. Accordingly, MSCs secretomes, rather than MSCs differentiation, are considered the primary way through which MSCs exert their therapeutic effects ${ }^{[9]}$ where the differentiated number of stem cells was very few to explain their magical reparative effects ${ }^{[10]}$.

These secretomes are partitioned based on their sizes and cellular origin into exosomes (EXOs), microvesicles (MVs) and apoptotic bodies; EXOs (30-150 nm) are produced in the endosomal system, MVs (100-1000 nm) and apoptotic bodies $(500-2000 \mathrm{~nm})$ both originate from the cell membrane. Both EXOs and MVs are released by the cells for intercellular communication and control of the recipient cells functions, via their contents (RNA, microRNA, proteins and others). However, apoptotic bodies are liberated from cells undergoing apoptosis to facilitate their phagocytosis ${ }^{[11]}$. Additionally, EXOs derived from MSCs (MSCs-EXOs) are of attracting interest as they are produced in large numbers and characterized by being stable, of low immunogenicity and well-tolerated in different body fluids ${ }^{[12]}$. Moreover, multiple recent studies proposed the potentiality of MSCs-EXOs as cell-free treatment in cases of $\mathrm{MI}^{[13]}$.

Heat shock proteins (Hsps), a family of endogenous proteins, produced in response to different cellular stresses and diseases such as hyperthermia ${ }^{[14]}$ and hypoxia ${ }^{[15]}$. They are considered as molecular chaperones i.e. they stabilize the cellular proteins through controlling folding and translocation of endogenous proteins and disposal of the incorrectly folded and the irretrievably denatured ones. So, they could protect the cells against these stresses and increase their survival ${ }^{[14]}$.

Heat shock protein70 (Hsp70) is the main Hsp involved in cardiac protection following MI where its induction decreases the infarct size and apoptosis of cardiac myocytes ${ }^{[16]}$. Furthermore, it was described that MSCs exposed to various forms of stresses (hypoxia and hyperthermia) during their culture, overexpressed Hsps (especially Hsp70) to augment their survival ${ }^{[17]}$.

This study was designed to evaluate and compare the potential therapeutic effect of non-HSBMMSCs-EXOs versus ${ }^{\mathrm{HS}} \mathrm{BMMSCs}-\mathrm{EXOs}$ on experimentally induced MI in adult male albino rats (acute and chronic stages), with highlighting the possible explanation for that difference.

\section{MATERIALS AND METHODS}

\section{Experimental Design}

Fifty-six adult male albino rats $(\sim 250 \mathrm{~g})$ were treated according to the guidelines granted by the Animal Use Committee of Cairo University(CU-III-F-12-20). The rats were housed in the Laboratory Animal House Unit of Kasr Al-Aini, Faculty of Medicine, Cairo University and divided as follows:

\section{Donor Group}

Two rats were used for BMMSCs isolation, culture, phenotyping, EXOs isolation and labelling.

\section{Experimental Groups}

The remaining animals were divided randomly into 4 main groups (control, MI, MI- ${ }^{\text {non-HS }}$ BMMSCs-EXOs \&MI${ }^{H S}$ BMMSCs-EXOs groups). Then the rats in each group were furtherly divided into 2 equal subgroups according to the time of sacrifice ( 3 and 28 days).

\section{Control Group (20 rats)}

The animals of each subgroup (10 rats) were subdivided into: Two rats, not subjected to any procedure. Two rats (sham-operated), subjected to the same procedure as those of MI group but without left anterior descending coronary artery occlusion (LCAO). Three rats, prepared as sham-operated rats then each rat was given intravenous (IV) injection of $400 \mu \mathrm{g}$ of PKH26 labelled ${ }^{\text {non-HS}}$ BMMSCsEXOs suspended in $200 \mu \mathrm{l}$ PBS via the tail vein. Three rats, prepared as the previous three rats but the animals were given PKH26 labelled ${ }^{\mathrm{HS}} \mathrm{BMMSCs}-\mathrm{EXOs}$ instead of ${ }^{\text {non-HS} B M M S C s-E X O s . ~}$

\section{Group (MI-3 and MI-28, 5 rats each)}

Animals of this group were subjected to permanent LCAO as previously described ${ }^{[18]}$ at the Laboratory Animal House Unit of Kasr Al-Aini, Faculty of Medicine, Cairo University. Briefly, the animals were anaesthetized with ketamine $(90 \mathrm{mg} / \mathrm{kg}) / \mathrm{xylazine}(15 \mathrm{mg} / \mathrm{kg})$ intraperitoneal (IP) injection and immobilized face-up on a warm pad. They were ventilated using a rodent ventilator through tracheal intubation. A left thoracotomy was done, between the $4^{\text {th }}$ and the $5^{\text {th }}$ intercostal spaces. Then lateral compression of the chest was applied to exteriorize the heart. Ligation of the left anterior descending coronary artery $(2 \mathrm{~mm}$ from its origin, between the left atrium border and the pulmonary artery sulcus) was achieved using 5-0-size silk suture thread. The heart was quickly returned to the thoracic cage, the lungs were inflated with $100 \%$ oxygen, positive ventilation and the wound was closed. Myocardial infarction was confirmed by colour loss in the area below the ligation point.

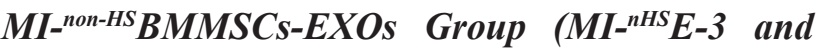 $M I-{ }^{n H S} E-28,6$ rats each)}

The rats in this group were subjected to permanent LCAO as in MI group. Immediately after LCAO, each rat was given IV injection of $400 \mu \mathrm{g}$ of PKH26 labelled ${ }^{n o n-H S} B M M S C s-E X O s$ suspended in $200 \mu$ PBS through the tail vein ${ }^{[1]}$.

\section{MI- ${ }^{H S}$ BMMSCs-EXOs Group (MI- ${ }^{H S} E-3$ and $M I-{ }^{H S} E-28,6$ rats each)}

The rats in this group were treated as in $\mathrm{MI}^{\mathrm{nHS}} \mathrm{E}$ group but they received PKH26 labelled ${ }^{\mathrm{HS}} \mathrm{BMMSCs}-\mathrm{EXOs}$ instead of ${ }^{\text {non-HS} B M M S C s-E X O s . ~}$ 


\section{In Vitro Studies}

\section{PKH26 labelled non-HSBMMSCs-EXOs \& ${ }^{H S}$ BMMSCS-EXOs}

They were purchased [as suspension of $400 \mu \mathrm{g}$ EXOs/200 $\mu$ l of phosphate-buffered saline (PBS)] from Stem Cell Research Unit, Biochemistry Department, Faculty of Medicine, Cairo University after being freshly prepared as follows:

\section{Isolation and Culture of BMMSCs}

This was done according to previously described methodology ${ }^{[19]}$ till the end of the 4th passage which was used in this study.

\section{Preparation of ${ }^{H S}$ BMMSCS ${ }^{[14]}$}

Part of BMMSCs was cultured in culture flasks $\left(3 \times 10^{4}\right.$ cells $/ \mathrm{cm}^{2}$ ), heat-sealed and immersed in a $42^{\circ} \mathrm{C}$ water bath for $60 \mathrm{~min}$. Then, they were incubated at $37^{\circ} \mathrm{C}$ for $24 \mathrm{~h}$ to recover before being used.

\section{${ }^{n o n-H S} B M M S C S-E X O S$ and ${ }^{H S} B M M S C S-E X O S$ Extraction $^{[20]}$}

Their extraction was done under complete aseptic conditions using differential centrifugation. Then, the exosomal pellets were re-suspended in PBS at $-80{ }^{\circ} \mathrm{C}$ to be used in this work.

\section{PKH26 Labelling of ${ }^{n o n-H S B M M S C s-E X O s}$ and ${ }^{H S}$ BMMSCs-EXOs ${ }^{[21]}$}

Using Red PKH26 Fluorescent Cell Linker Kit (Sigma, USA, MINI26) according to the manufacturer's protocol.

\section{Measuring Value of heat shock factor 1 (HSF1) in ${ }^{n o n-H S} B M M S C s-E X O s$ and ${ }^{H S} B M M S C s-E X O s$}

This was accomplished at Biochemistry Department, Faculty of Medicine, Cairo University, using EnzymeLinked ImmunoSorbent Assay (ELISA) according to manufacturer's instructions after adding $100 \mathrm{ml}$ of each exosomal samples to the primary HSF1 antibody (rat monoclonal antibody, MA5-27688, Invitrogen, ThermoFisher Scientific, USA) in the wells of a 96-well plate of an ELISA kit (R\&D system, USA).

\section{Animal Studies}

\section{Serological Study}

Just before the sacrifice of each experimental group, blood samples from the tail vein were obtained to measure the serum level of the early MI markers [creatine phosphokinase (CPK) and lactate dehydrogenase (LDH) ${ }^{[22]}$ using spectrophotometer (UV-1601PC, Shimadzu, Japan). This was done at Biochemistry Department, Faculty of Medicine, Cairo University.

\section{Animals sacrifice}

At the Laboratory Animal House Unit of Kasr Al-Aini, Faculty of Medicine, Cairo University, the rats were sacrificed by cervical dislocation after being anaesthetized with IP injection of ketamine $(90 \mathrm{mg} /$ $\mathrm{kg}) / x y l a z i n e ~(15 \mathrm{mg} / \mathrm{kg})^{[23]}$. Two of the control animals received non-HSBMMSCs-EXOs and another two received ${ }^{\mathrm{HS}} \mathrm{BMMSCs-EXOs}$ together with one animal from subgroups MI- ${ }^{\mathrm{nHS}} \mathrm{E}-3$, MI- ${ }^{\mathrm{nHS}} \mathrm{E}-28, \mathrm{MI}-{ }^{\mathrm{HS}} \mathrm{E}-3$ and MI- ${ }^{\mathrm{HS}} \mathrm{E}-28$ were sacrificed 1 day after EXOs administration while the remaining animals were sacrificed after 3 and 28 days. The chests were opened and the hearts were dissected. Three slices $(2-2.5 \mathrm{~mm}$ in thickness) were longitudinally sliced from the apex to the base of the left ventricles (one for quantitative real-time polymerase chain reaction [qRT-PCR], one for preparation of cardiac homogenates and one for histological examination).

\section{Quantitative real-time polymerase chain reaction $(q R T-P C R)^{[24]}$}

It was done at Biochemistry Department, Faculty of Medicine, Cairo University to detect relative mRNA expression of Bax (pro-apoptotic gene) and microRNA34a (miR-34a): After total RNA extraction and complementary DNA (cDNA) synthesis, qRT-PCR of the studied genes was done using Rotor Gene 6000 series software version 1.7 (Corbett Life Science, USA) and the primers. Then the results were expressed as a normalized ratio. The PCR primer sequences used were Bax (forward: 5'- GTTGCCCTCTTCTACTTTG-3'; reverse: 5'- AGCCACCCTGGTCTTG -3'), miR-34a (forward: 5'- TTGAATTCTAACACCTTCGTGGCTACAGAG-3'; reverse:5-TTAGATCTCATTTATCGAGGGAAGG ATTG-3') and GAPDH [internal control] (Forward: 5'- CTCCCATTCTTCCACCTTTG-3'; Reverse: 5'- CTTGCTCTCAGTATCCTTGC-3').

\section{Cardiac Homogenates and ELISA}

Cardiac homogenates were done at Biochemistry Department, Faculty of Medicine, Cairo University, based on previous methodology ${ }^{[24]}$. Then ELISA was done according to the manufacturer's instructions to measure values of HSF1 and Hsp70 using a 96-well plate of a rat ELISA kit (R\&D system, USA) and primary antibodies for HSF1 (rat monoclonal antibody, MA5-27688, Invitrogen, ThermoFisher Scientific, USA) and for Hsp70 (mouse monoclonal antibody, 33-3800, Invitrogen, ThermoFisher Scientific, USA).

\section{Histological Study}

At Histology Department, Faculty of Medicine, Cairo University, the slices for the histological examination were fixed in $10 \%$ formol saline for $24 \mathrm{~h}$. Paraffin blocks were processed and $5 \mu \mathrm{m}$ thick sections were cut:

Unstained sections of the control group and subgroups MI- ${ }^{\mathrm{nHS}}$ E-3, MI- ${ }^{\mathrm{HHS}} \mathrm{E}-28$, MI- ${ }^{\mathrm{HS}} \mathrm{E}-3$ \& MI- ${ }^{\mathrm{HS}} \mathrm{E}-28$ sacrificed after 1 day were examined by the fluorescent microscope. However, sections of different groups sacrificed after 3 and 28 days were subjected to: 
Hematoxylin and Eosin stain $(H \& E)^{[25]}$.

Masson's trichrome stain ${ }^{[26]}$.

\section{Immunohistochemical staining for:}

a. Caspase 3 (rabbit polyclonal antibody, ab4051, abcam, USA): it appears as a cytoplasmic reaction in the apoptotic cells.

b. Connexin 43 (rabbit polyclonal antibody, ab11370, abcam, USA): it is a marker for gap junction of the intercalated discs. It appears as a membranous reaction (at the sites of connection between the adjacent cardiomyocytes).

c. HSF1 (rabbit polyclonal antibody, ab131081, abcam, USA): it appears as a cytoplasmic and/or nuclear reactions localizing HSF1.

d. Hsp70 (mouse monoclonal antibody, MA3-008, Invitrogen, ThermoFisher Scientific, USA): it is a marker for Hsp70 that appears as a cytoplasmic reaction.

Immunostaining using avidin-biotin technique required pretreatment ${ }^{[26]}$, this was carried out by 10 min boiling in $10 \mathrm{mM}$ citrate buffer (cat no 005000) pH 6 for antigen retrieval. Sections were left to cool for $20 \mathrm{~min}$ in room temperature. Then, incubation of the sections for one hour with the primary antibodies was done. Immunostaining was completed by the use of Ultravision One Detection System (cat no TL - 060- HLJ). Counterstaining was carried out using Lab Vision Mayer's hematoxylin (cat no TA- 060$\mathrm{MH})$. Negative control sections were prepared by the same process after excluding the primary antibodies. Citrate buffer, Ultravision One Detection System and Ultravision Mayer's hematoxylin were purchased from Labvision, ThermoFisher Scientific, USA.

\section{Morphometric study}

Image analysis by Leica Qwin-500 LTD-software image analysis computer system (Cambridge, England) was done at Histology Department, Faculty of Medicine, Cairo University to measure mean area percent of collagen fibres in Masson's trichrome-stained sections and of caspase 3, connexin 43, HSF1 and Hsp70 immuno-expression in the corresponding immunostained sections. Each of these measurements was done in ten non-overlapping fields $(\times 100)$.

\section{Statistical analysis ${ }^{[2]}$}

All morphometric and biochemical measurements were expressed as mean \pm standard deviation (SD). They were statistically analyzed using one-way analysis of variance (ANOVA) followed by "tukey" post hoc test for all measurements except exosomal HSF1 level where independent samples T-test was used. All calculations were done using the IBM Statistical Package for the Social
Sciences (SPSS) version 21 the results were considered statistically significant when $P$-value was $<0.05$.

\section{RESULTS}

\section{General observations}

Lethargy was observed in MI subgroups throughout the whole experimental duration and in subgroup MI- ${ }^{\mathrm{nHS}} \mathrm{E}-28$, 7 days after induction of MI. No deaths nor abnormal behaviour was observed in any of the experimental animals.

Similar serological, biochemical and histological results were found in the control subgroups so, they were collectively called the control group.

\section{ELISA Results for Exosomal HSF1}

Mean level of HSF1 was $8.30 \pm 0.50$ and $17.56 \pm 1.34$ $\mathrm{ng} / \mathrm{ml}$ in ${ }^{\text {non-HS}}$ BMMSCs-EXOs and ${ }^{\mathrm{HS}}$ BMMSCs-EXOs, respectively. Statistically, this indicated a significant increase in ${ }^{H S}$ BMMSCs-EXOs when compared to non-HSBMMSCs-EXOs.

\section{Animal Data}

\section{Serological Results (Table 1)}

Levels of cardiac enzymes (CPK \& LDH) showed a significant increase in all experimental subgroups versus the control group except subgroups $\mathrm{MI}^{\mathrm{HS}} \mathrm{E}-3$ \& MI- ${ }^{\mathrm{HS}} \mathrm{E}-28$. Additionally, there was significant decrease in subgroups MI-28 \& MI- ${ }^{\mathrm{nHS}}$ E-28 when compared to subgroups MI-3 \& MI- ${ }^{\mathrm{nHS}} \mathrm{E}-3$, respectively and in subgroup MI- ${ }^{\mathrm{nHS}} \mathrm{E}-3$ versus subgroup MI-3. Moreover, there was significant decrease in subgroup MI- ${ }^{\mathrm{HS}} \mathrm{E}-3$ versus subgroups MI-3 \& MI- ${ }^{\mathrm{nHS}} \mathrm{E}-3$ and in subgroup MI-HSE-28 versus subgroups MI-28 \& MI- ${ }^{\mathrm{nHS}} \mathrm{E}-28$.

\section{QRT-PCR Results for cardiac Bax and miR-34a (Table 1)}

Levels of both Bax and miR-34a expressions revealed significant increase in all experimental subgroups except subgroups MI- ${ }^{\mathrm{HS}} \mathrm{E}-3$ \& MI- ${ }^{\mathrm{HS}} \mathrm{E}-28$ versus the control group. Also, there was a significant decrease in subgroups MI-28 \& MI- ${ }^{\mathrm{nHS}}$ E-3 versus subgroup MI-3 and a significant increase in subgroup $\mathrm{MI}-{ }^{\mathrm{nHS}} \mathrm{E}-28$ versus subgroup MI-nHSE-3. Subgroup MI- ${ }^{\mathrm{HS}} \mathrm{E}-3$ showed a significant decrease versus subgroups MI-3 \& MI- ${ }^{\mathrm{nH}} \mathrm{E}-3$ and subgroup MI- ${ }^{\mathrm{HS}} \mathrm{E}-28$ demonstrated a significant decrease versus subgroups MI-28 \& MI- ${ }^{\mathrm{nHS}} \mathrm{E}-28$.

\section{ELISA Results for HSF1 and Hsp70 in Cardiac Homogenates (Table 1)}

Levels of HSF1 \& Hsp70 demonstrated a significant increase in subgroups MI-3, MI- ${ }^{\mathrm{HS}} \mathrm{E}-3$ \& $\mathrm{MI}-{ }^{\mathrm{HS}} \mathrm{E}-3$ than control group, subgroups MI-3 and MI- ${ }^{\mathrm{nHS}} \mathrm{E}-3$, correspondingly. In addition, there was a significant decrease in subgroups MI-28 \& MI- ${ }^{\mathrm{nHS}} \mathrm{E}-28$ versus subgroups MI-3 \& MI- ${ }^{\mathrm{nHS}} \mathrm{E}-3$, respectively. Furthermore, subgroup $\mathrm{MI}-{ }^{\mathrm{HS}} \mathrm{E}-28$ demonstrated a significant increase than subgroups MI-28, MI- ${ }^{\mathrm{nHS}}$ E-28 \& control group. 


\section{Histological Results}

\section{Fluorescent labelled sections}

PKH26 labelled BMMSCs-EXOs were absent in control rats received non-HSBMMSCs-EXOs (Figure 1a) and ${ }^{\mathrm{HS}} \mathrm{BMMSCs-EXOs} \mathrm{(Figure} \mathrm{1b)} \mathrm{and} \mathrm{present}$ in subgroups MI- ${ }^{\mathrm{nHS}} \mathrm{E}$ (Figure 1c) \& MI- ${ }^{\mathrm{HS}} \mathrm{E}$ (Figure 1d).

\section{$H \& E$ stained sections}

In the control group (Figure 2a), the myocardium was formed of longitudinally cut transversely striated cardiac myocytes with central oval pale nuclei. They were joined together by intercalated discs and appeared branching and anastomosing forming muscle sheets. In-between the cardiac myocytes, there was a delicate layer of CT with well-demonstrated blood vessels. In subgroups MI-3 and MI-28 (Figures 2b, 2c), the myocardium demonstrated structural disorganization with features of inflammation and cellular damage that were more obvious in subgroup MI-3. However, widening of the intercellular spaces with active fibroblasts (pale nuclei) and thickened CT was more evident in subgroup MI-28. Sections of subgroup MI- ${ }^{\mathrm{nHS}} \mathrm{E}-3$ (Figure 2d) presented minimal features of myocardial lesion. Whereas, sections of subgroup MI- ${ }^{\mathrm{nHS}}$ E-28 (Figure 2e) showed marked deterioration of the myocardial histological structure to be similar to that of subgroup MI-28. Nearly normal histological architecture was shown in subgroups $\mathrm{MI}-{ }^{\mathrm{HS}} \mathrm{E}-3$ and MI- ${ }^{\mathrm{HS}} \mathrm{E}-28$ (Figures 2f, 2g), except for the presence of very few shrunken darkly stained nuclei.

\section{Masson's trichrome stained sections}

Occasional collagen fibers were shown in the intercellular $\mathrm{CT}$ of the control group, subgroups MI- ${ }^{\mathrm{nHS}} \mathrm{E}-3, \quad \mathrm{MI}-{ }^{\mathrm{HS}} \mathrm{E}-3$ and $\mathrm{MI}-{ }^{\mathrm{HS}} \mathrm{E}-28$ (Figures 3a, 3d, 3f, 3g). However, this amount was increased in subgroup MI-3 (Figure 3b) to become abundant in subgroups MI-28 and MI- ${ }^{\mathrm{nHS}} \mathrm{E}-28$ (Figures 3c, 3e).

\section{Caspase 3 immunostained sections}

The positive immunoreaction was sporadic in the control group (Figure 4a), dramatically increased in subgroup MI-3 (Figure 4b), moderate in subgroups MI-28, MI- ${ }^{\mathrm{nHS}} \mathrm{E}-3$ and MI- ${ }^{\mathrm{nHS}} \mathrm{E}-28$ (Figures 4c, 4d, 4e) and infrequent in subgroups $\mathrm{MI}-{ }^{\mathrm{HS}} \mathrm{E}-3$ and $\mathrm{MI}-{ }^{\mathrm{HS}} \mathrm{E}-28$ (Figures 4f, 4g).

\section{Connexin 43 immunostained sections}

Abundant positive immunoreaction was visualized in the control group (Figure 5a), then the reaction was radically reduced in subgroups $\mathrm{MI}-3$, MI-28 and MI${ }^{n H S} \mathrm{E}-28$ (Figures 5b, 5c, 5e). In subgroups MI- ${ }^{\mathrm{nHS}} \mathrm{E}-3$, MI- ${ }^{\mathrm{HS}} \mathrm{E}-3$ and $\mathrm{MI}{ }^{-\mathrm{HS}} \mathrm{E}-28$, the positive immunoreaction regained its abundance (Figures 5d, 5f, 5g).

\section{HSF1 immunostained sections}

Widely spread positive immunoreaction was detected in subgroups MI-3, MI- ${ }^{\mathrm{nHS}} \mathrm{E}-3, \mathrm{MI}-{ }^{\mathrm{HS}} \mathrm{E}-3$ and $\mathrm{MI}-{ }^{\mathrm{HS}} \mathrm{E}-28$ (Figures 6b, 6d, 6f, 6g). This was in contrast to the reduced reaction recognized in the control group, subgroups MI-28 and MI- ${ }^{\mathrm{nHS}} \mathrm{E}-28$ (Figures 6a, 6c, 6e).

\section{Hsp70 immunostained sections}

The demonstrated positive immunoreaction increased gradually from control group and subgroups MI-28 and MI ${ }^{\mathrm{nHS}} \mathrm{E}-28$ (Figures $7 \mathrm{a}, 7 \mathrm{c}, 7 \mathrm{e}$ ) passing through subgroups MI-3 and MI-nHSE-3 (Figures 7b, 7d) to subgroups MI- ${ }^{\mathrm{HS}} \mathrm{E}-3$ and $\mathrm{MI}-{ }^{\mathrm{HS}} \mathrm{E}-28$ where it appeared in most of the myocytes (Figures 7f, 7g).

\section{Morphometric Results}

Mean area percent of collagen fibres (Figure $3 \mathrm{~h}$ ) showed a significant increase in subgroups MI-3, MI-28 and $\mathrm{MI}{ }^{-{ }^{\mathrm{HS}}} \mathrm{E}-28$ when compared with the control group and subgroups MI-3 and MI- ${ }^{\mathrm{nHS}} \mathrm{E}-3$, respectively. Also, there was a significant decrease in subgroup MI- ${ }^{n H S}$ E-3 versus MI-3 and its significant increase versus the control group. Moreover, a significant decrease in subgroups MI- ${ }^{\mathrm{HS}} \mathrm{E}-3$ and MI- ${ }^{\mathrm{HS}} \mathrm{E}-28$ compared to subgroups MI- ${ }^{\mathrm{HHS}} \mathrm{E}-3$ and MI${ }^{n H S} \mathrm{E}-28$, correspondingly was detected. Besides, significant decrease in subgroup MI- ${ }^{\mathrm{HS}} \mathrm{E}-28$ versus subgroup MI-28 was reported.

Caspase 3 mean area percent (Figure $4 \mathrm{~h}$ ) revealed similar result to that of the statistical analysis of Bax level.

Regarding the mean area percent of connexin 43 (Figure 5h), it revealed a significant decrease in subgroups MI-3, MI-28 and MI- ${ }^{\mathrm{nHS}}$ E-28 when compared with the control group and subgroups MI-3 and MI${ }^{n H S}$ E-3, correspondingly. Additionally, subgroup MI${ }^{n H S}$ E-3 showed a significant increase than MI-3 and a significant decrease than the control group. Moreover, there was a significant increase in subgroups $\mathrm{MI}-{ }^{\mathrm{HS}} \mathrm{E}-3$ and MI- ${ }^{\mathrm{HS}} \mathrm{E}-28$ versus subgroups $\mathrm{MI}-{ }^{\mathrm{nHS}} \mathrm{E}-3$ and $\mathrm{MI}-{ }^{\mathrm{nHS}} \mathrm{E}-28$, respectively. Furthermore, subgroup $\mathrm{MI}-{ }^{\mathrm{HS}} \mathrm{E}-28$ exposed significant increase versus subgroup MI-28.

Mean area percent of HSF1 and Hsp70 (Figures 6h,7h) revealed results parallel to the statistical results of their biochemical levels. 


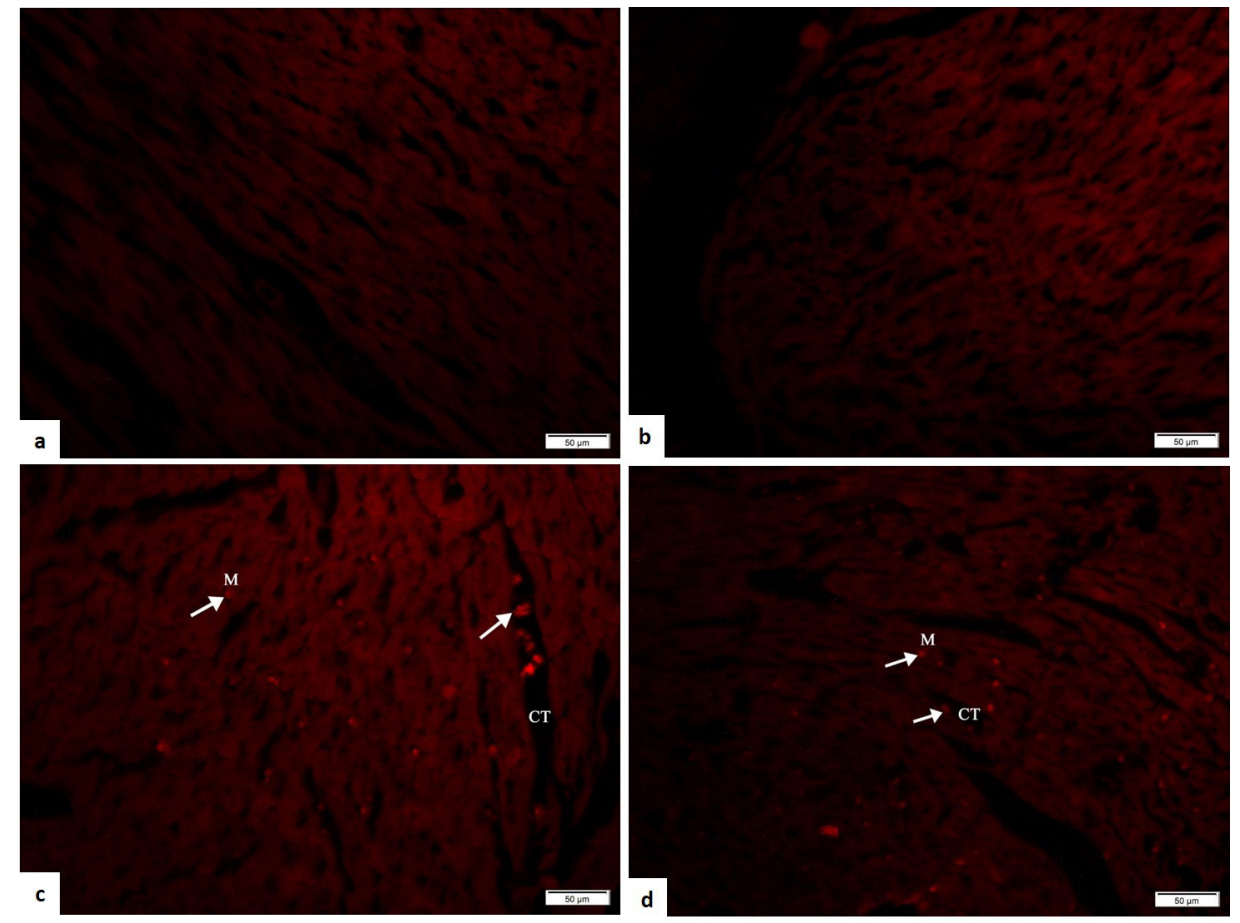

Fig. 1: showing (a \& b) absence of PKH26 labeled BMMSCs-EXOs in both control subgroups received ${ }^{\text {non-HS} B M M S C s-E X O s ~ \& ~}{ }^{\mathrm{HS}}$ BMMSCs-EXOs. (c \& d) presence of PKH26 labeled ${ }^{\text {non-HS} B M M S C s-E X O s ~ a n d ~}{ }^{\mathrm{HS} B M M S C s-E X O s ~(a r r o w s) ~ i n ~ t h e ~ c o n n e c t i v e ~ t i s s u e ~(C T) ~ a n d ~ c a r d i a c ~ m y o c y t e s ~(M) ~ o f ~ s u b g r o u p s ~}$ MI- ${ }^{\mathrm{nHS}} \mathrm{E} \& \mathrm{MI}-{ }^{\mathrm{HS}} \mathrm{E}$, respectively. (PKH26, x 200)
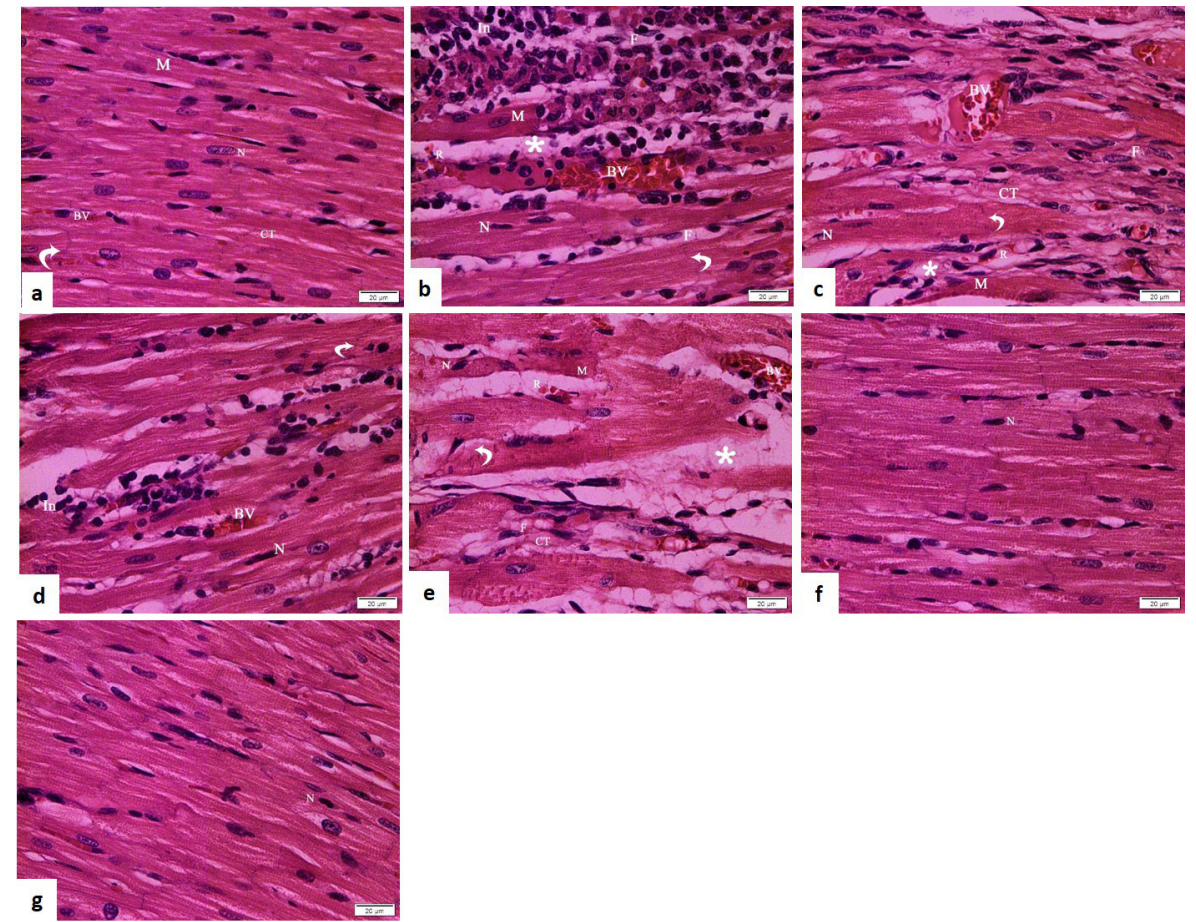

Fig. 2: showing (a) cylindrical branching and anastomosing longitudinally arranged cardiac muscle fibers (M) joined by intercalated discs (curved arrow), exhibiting transversely striated acidophilic sarcoplasm and central oval pale nuclei (N) and separated by delicate CT (CT) with blood vessels (BV) in the control group. (b) widening of the intercellular spaces (star), a dilated congested blood vessel (BV), extra-vasated RBCs (R), mononuclear cellular infiltration (In), active fibroblasts (F), disruption of the intercalated discs (curved arrow), myocytes (M) with deeply acidophilic sarcoplasm and lost striations and others with shrunken darkly stained nuclei (N) in subgroup MI-3. (c) enormous widening of the intercellular spaces (star), obvious CT (CT) thickening, numerous active fibroblasts (F), blood vessels (BV) dilatation and congestion, extra-vasated RBCs (R), disrupted intercalated disc (curved arrow) and few myocytes (M) with deeply acidophilic sarcoplasm and lost striations or shrunken darkly stained nuclei (N) in subgroup MI-28. (d) few shrunken condensed nuclei (N), intact intercalated discs (curved arrow), minimal inflammatory cell infiltration (In) and a dilated congested blood vessel (BV) in subgroup MI- ${ }^{\text {HHS }}$ E-3. (e) wide intercellular spaces (star), thickened CT (CT), active fibroblasts (F), a dilated congested blood vessel (BV), extra-vasated RBCs (R), disrupted intercalated discs (curved arrow), myocytes (M) with deeply acidophilic sarcoplasm and lost striations, shrunken darkly stained nuclei (N) in subgroup MI- ${ }^{\mathrm{HHS}} \mathrm{E}-28$. (f \& g) very few shrunken darkly stained nuclei $(\mathrm{N})$ in subgroups $\mathrm{MI}-{ }^{\mathrm{HS}} \mathrm{E}-3$ \&MI-HS $\mathrm{E}-28$. (H\&E, x400) 


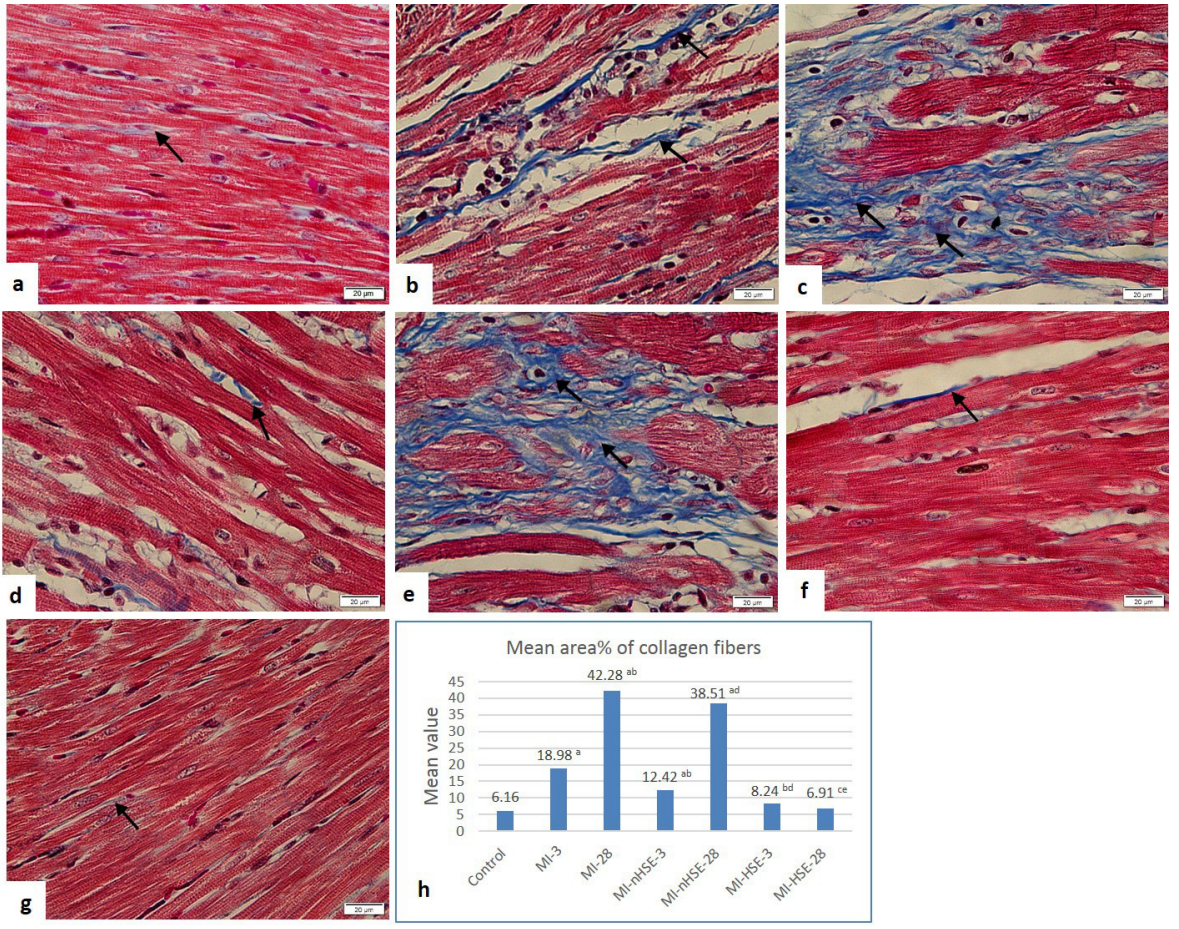

Fig. 3: demonstrating: ( $a, d, f \&$ ) occasional fine collagen fibers (arrow) in control group, subgroups MI- ${ }^{\mathrm{nHS}} \mathrm{E}-3, \mathrm{MI}-{ }^{\mathrm{HS}} \mathrm{E}-3$ \& $\mathrm{MI} \mathrm{H}^{\mathrm{HS}} \mathrm{E}-28$. (b) increased collagen fibers content (arrows) in subgroup MI-3. (c \& e) copious collagen fibers (arrows) in subgroups MI-28 \& MI- ${ }^{\mathrm{nHS}} \mathrm{E}-28$. (Masson's trichrome, $\left.\times 400\right)(\mathrm{h})$ showing mean area $\%$ of collagen fibers: a, b, c, d \&e as compared to control group \& subgroups MI-3, MI-28, MI- ${ }^{\mathrm{nHS}} \mathrm{E}-3$ \&MI- ${ }^{\mathrm{nHS}} \mathrm{E}-28$, respectively (significant difference at $P<0.05$ )

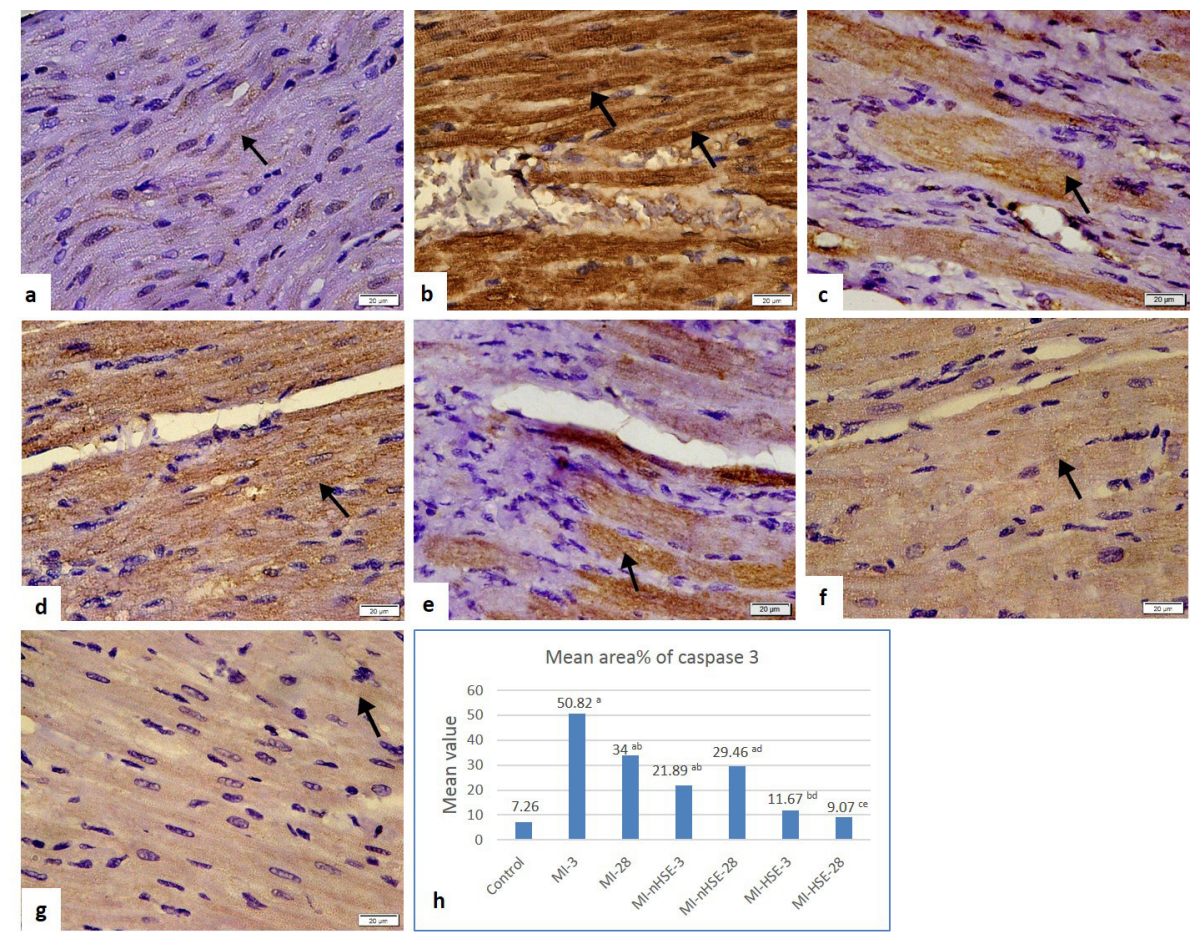

Fig. 4: showing positive cytoplasmic immunoreaction (arrow) in: (a) very few myocytes in control group. (b) almost all myocytes in subgroup MI-3. (c, d \& e) some myocytes in subgroups MI-28, MI- ${ }^{\mathrm{nHS}} \mathrm{E}-3$ \& MI- ${ }^{\mathrm{nHS}} \mathrm{E}-28$. (f \& g) few myocytes in subgroups MI- ${ }^{\mathrm{HS}} \mathrm{E}-3$ \&MI- ${ }^{\mathrm{HS}} \mathrm{E}-28$. (Immunohistochemical stain for caspase $3, \mathrm{x} 400$ ) (h) showing mean area $\%$ caspase $3: \mathrm{a}, \mathrm{b}, \mathrm{c}, \mathrm{d} \& \mathrm{e}$ as compared to control group \& subgroups MI-3, MI-28, MI- ${ }^{\mathrm{nH}} \mathrm{E}-3$ \&MI-- ${ }^{\mathrm{nHS}} \mathrm{E}-28$, respectively (significant difference at $P<0.05$ ) 

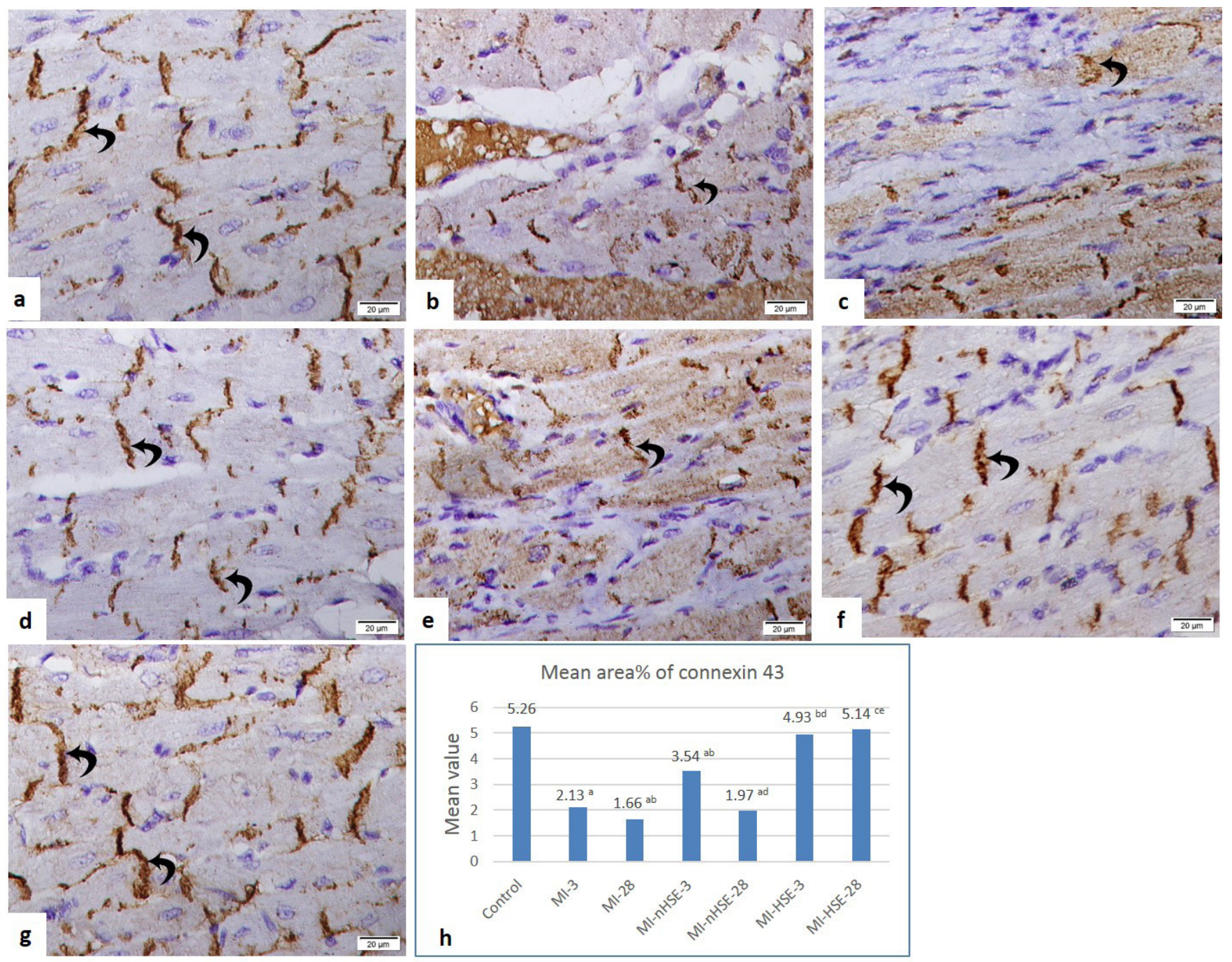

Fig. 5: Showing positive membranous immunoreaction (curved arrow) which is: (a, d, f \& g) abundant in control group and subgroups ${ }^{-{ }^{n H S}}{ }^{-}-3$, MI- ${ }^{-{ }^{\mathrm{SS}}}{ }^{\mathrm{E}-3}$ and MI- ${ }^{\mathrm{HS}} \mathrm{E}-28$. (b, c \& e) minimal in subgroups MI-3, MI-28 and MI- ${ }^{\mathrm{nHS}} \mathrm{E}-28$. (Immunohistochemical stain for connexin 43, $\mathrm{x} 400$ ) (h) showing mean area \% of connexin 43: a, b, c, d \&e as compared to control group \& subgroups MI-3, MI-28, MI- ${ }^{\mathrm{nHS}} \mathrm{E}-3$ \&MI- ${ }^{\mathrm{nHS}} \mathrm{E}-28$, respectively (significant difference at $P<0.05$ )

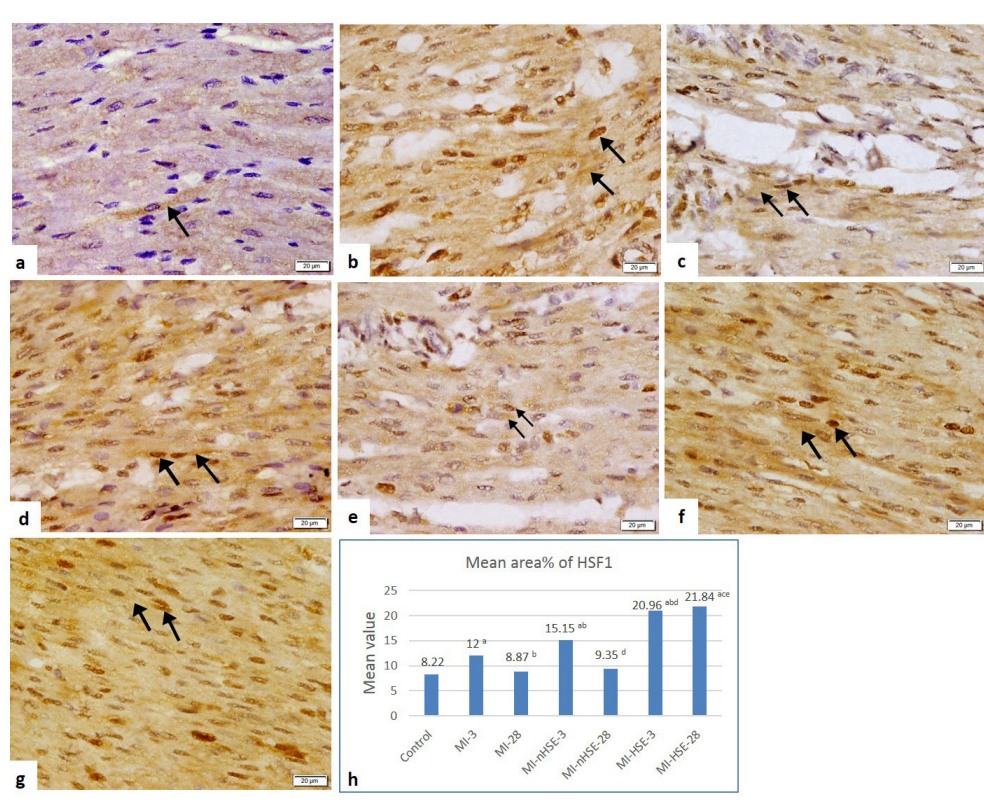

Fig. 6: Revealing positive immunoreactivity (arrow) in: (a) cytoplasm of some myocytes in control group. (b, d, f, \& g) nuclei and cytoplasm of most of the muscle fibers in subgroups MI-3, MI- ${ }^{\mathrm{nHS}} \mathrm{E}-3, \mathrm{MI}-{ }^{\mathrm{HS}} \mathrm{E}-3$ and $\mathrm{MI}-{ }^{\mathrm{HS}} \mathrm{E}-28$. (c \& e) nuclei and cytoplasm of some of the cardiac myocytes in subgroups MI-28 and MI${ }^{\mathrm{nHS}} \mathrm{E}-28$. (Immunohistochemical stain for HSF1, x400)

(h) showing mean area \% HSF1: a, b, c, d \&e as compared to control group \& subgroups MI-3, MI-28, MI- ${ }^{\mathrm{HHS}} \mathrm{E}-3$ \&MI- ${ }^{\mathrm{nHS}} \mathrm{E}-28$, respectively (significant difference at $P<0.05$ ) 

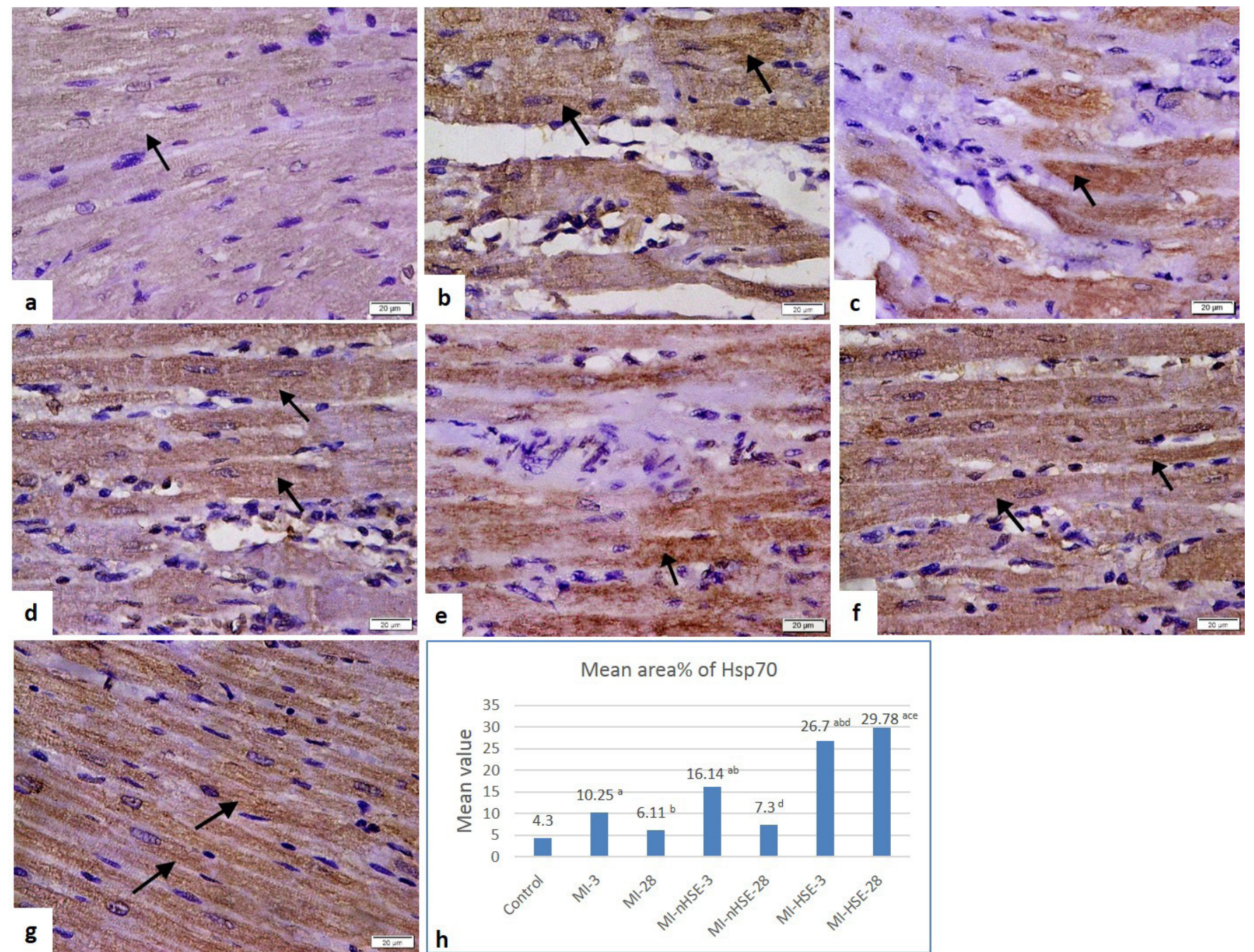

Fig. 7: Illustrating positive cytoplasmic immunoreaction (arrow) in: (a) some myocytes of control group. (b, c, d \& e) more muscle fibers in subgroups MI-3, MI-28, MI- ${ }^{\mathrm{nHS}} \mathrm{E}-3$ \&MI- ${ }^{\mathrm{HHS}} \mathrm{E}-28$. (f \& g) most of the fibers in subgroups MI- ${ }^{\mathrm{HS}} \mathrm{E}-3$ and MI- ${ }^{\mathrm{HS}} \mathrm{E}-28$. (Immunohistochemical stain for Hsp70, $\mathrm{x} 400$ ) (h) showing mean area \% of Hsp70: a, b, c, d \&e as compared to control group \& subgroups MI-3, MI-28, MI- ${ }^{\mathrm{nHS}}$ E-3 \&MI- ${ }^{\mathrm{nHS}}$ E-28, respectively (significant difference at $P<0.05)$

Table 1: Mean value \pm SD of biochemical parameters in all groups

\begin{tabular}{|c|c|c|c|c|c|c|c|}
\hline & $\begin{array}{l}\text { Control } \\
\text { group }\end{array}$ & $\begin{array}{l}\text { Subgroup } \\
\text { MI-3 }\end{array}$ & $\begin{array}{l}\text { Subgroup } \\
\text { MI-28 }\end{array}$ & $\begin{array}{l}\text { Subgroup } \\
\text { MI-nHSE-3 }\end{array}$ & $\begin{array}{c}\text { Subgroup } \\
\text { MI- }{ }^{\mathrm{nHS}} \text { E-28 }\end{array}$ & $\begin{array}{l}\text { Subgroup } \\
\text { MI- }{ }^{\mathrm{HS}} \mathrm{E}-3\end{array}$ & $\begin{array}{l}\text { Subgroup } \\
\text { MI-Hs E-28 }\end{array}$ \\
\hline $\begin{array}{c}\text { Serum CPK } \\
(\mathrm{U} / \mathrm{L})\end{array}$ & $117.60 \pm 10.52$ & $234.10 \pm 9.09$ & $184.50 \pm 21.56^{\mathrm{ab}}$ & $199.9 \pm 16.31^{\mathrm{ab}}$ & $171.60 \pm 14.22^{\mathrm{ad}}$ & $131.90 \pm 7.74^{\text {bd }}$ & $124.30 \pm 11.35^{\mathrm{ce}}$ \\
\hline $\begin{array}{l}\text { Serum LDH } \\
(\mathrm{U} / \mathrm{L})\end{array}$ & $143.10 \pm 13.04$ & $330.00 \pm 18.37$ & $211.50 \pm 14.75^{\mathrm{ab}}$ & $243.70 \pm 11.32^{\mathrm{ab}}$ & $197.50 \pm 15.54^{\mathrm{ad}}$ & $157.40 \pm 6.87^{\text {bd }}$ & $149.80 \pm 10.03^{\mathrm{ce}}$ \\
\hline $\begin{array}{c}\text { Cardiac Bax } \\
\text { expression }\end{array}$ & $0.16 \pm 0.01$ & $1.56 \pm 0.15^{\mathrm{a}}$ & $1.12 \pm 0.10^{\mathrm{ab}}$ & $0.74 \pm 0.15^{\mathrm{ab}}$ & $1.05 \pm 0.12^{\mathrm{ad}}$ & $0.30 \pm 0.03^{\mathrm{bd}}$ & $0.20 \pm 0.04^{\text {ce }}$ \\
\hline $\begin{array}{l}\text { Cardiac miR-34a } \\
\text { expression }\end{array}$ & $1.04 \pm 0.14$ & $3.87 \pm 0.43^{\mathrm{a}}$ & $2.48 \pm 0.41^{\mathrm{ab}}$ & $1.66 \pm 0.05^{\mathrm{ab}}$ & $2.17 \pm 0.22^{\mathrm{ad}}$ & $1.31 \pm 0.05^{\mathrm{bd}}$ & $1.26 \pm 0.07^{\mathrm{ce}}$ \\
\hline $\begin{array}{l}\text { Cardiac HSF1 } \\
\text { (ng/mg ptn) }\end{array}$ & $4.96 \pm 0.28$ & $7.86 \pm 0.52^{\mathrm{a}}$ & $5.11 \pm 0.47^{\mathrm{b}}$ & $9.09 \pm 0.61^{\mathrm{ab}}$ & $5.66 \pm 0.42^{\mathrm{d}}$ & $12.89 \pm 0.63^{\mathrm{abd}}$ & $13.65 \pm 0.91^{\text {ace }}$ \\
\hline $\begin{array}{l}\text { Cardiac Hsp70 } \\
\text { (pg/mg ptn) }\end{array}$ & $3.20 \pm 0.31$ & $8.58 \pm 1.11^{\mathrm{a}}$ & $3.61 \pm 0.40^{\mathrm{b}}$ & $11.37 \pm 0.94^{\mathrm{ab}}$ & $4.00 \pm 0.40^{\mathrm{d}}$ & $13.84 \pm 1.61^{\mathrm{abd}}$ & $15.02 \pm 1.19^{\text {ace }}$ \\
\hline
\end{tabular}

${ }^{\text {a }} P<0.05$ as compared to control group

${ }^{\mathrm{b}} P<0.05$ as compared to subgroup MI-3

${ }^{c} P<0.05$ as compared to subgroup MI-28

${ }^{\mathrm{d}} P<0.05$ as compared to subgroup MI- ${ }^{\mathrm{nHS}} \mathrm{E}-3$

${ }^{\mathrm{e}} P<0.05$ as compared to subgroup MI- ${ }^{\mathrm{nHS}} \mathrm{E}-28$ 


\section{DISCUSSION}

This work aimed at assessing and comparing the potential therapeutic influence of non-HSBMMSCs-EXOs versus ${ }^{\mathrm{HS}} \mathrm{BMMSCs-EXOs}$ on experimentally induced MI (acute and chronic stages) in adult albino rats and underlining the possible explanation for that difference. Male rats were chosen for this study to avoid the protective effect of the female hormone (estrogen) on the cardiac muscle $^{[28]}$.

Heat shock factor 1 (HSF1) is a naturally present inactive cytoplasmic protein that becomes activated by phosphorylation after any cellular stress. The phosphorylated HSF1 (p-HSF1) is translocated to the nucleus where it activates the transcription of Hsp70 gene with a consequent increase in its production ${ }^{[15]}$. The link between p-HSF1 and Hsp70 was found to be through pro-apoptotic miR-34a where p-HSF1 binds to the promotor region of miR-34a gene preventing its transcription. Recently, miR-34a was known to be a suppressor for Hsp70 gene through blocking of its promotor region. So, suppression of miR-34a was documented to increase the production of $\mathrm{Hsp} 70^{[17]}$.

Based on that, the hypoxia occurred during the acute stage of MI in the current study with its subsequent release of reactive oxygen species (ROS) and oxidative stress OS ${ }^{[29]}$ demonstrated a significant increase of HSF1 and Hsp70, both biochemically and immunohistochemically, than the control group which was similarly reported for Hsp $70^{[16]}$. However, this increase in HSF1 was suggested not to be sufficient to suppress the increased miR-34a production occurred secondary to increased P53 protein induced by severe hypoxia ${ }^{[30,31]}$. This suggestion was enforced by the significant increase in miR-34a level in subgroup MI-3 when compared to control.

This increase in miR-34a together with the persistent lesion led to inevitable myocytes apoptosis documented by deeply eosinophilic sarcoplasm, pyknotic nuclei and a significant increase in caspase 3 area percent and Bax level in subgroup MI-3 versus the control group. Such apoptotic cell death was similarly stated in a previous study ${ }^{[29]}$. Additionally, there was a significant increase in the serum levels of the cardiac enzymes (CPK and LDH) in this subgroup. This finding could be explained by the cardiac myocytes' membrane damage with subsequent prompt release of the cardiac enzymes to blood resulted from hypoxia-induced $\mathrm{OS}^{[32]}$.

Cardiac myocytes death was found to disrupt the cardiac contractility and functionality through disruption of the intercalated discs and their gap junction. This suggestion was enforced by the significant decrease in the area percent of connexin 43 in this subgroup compared to the control group. Further support came from the former study ${ }^{[1]}$ in which left coronary artery ligation was followed by cardiac myocytes apoptosis and cardiac functions deterioration.

Moreover, hypoxia-induced OS is followed by the production of pro-inflammatory cytokines such as interleukin-6 (IL-6) and tumour necrosis factor (TNF)- $\alpha$, and initiation of the inflammatory respons $\mathrm{e}^{[33]}$. This was supported, in subgroup MI-3, by dilatation and congestion of the blood vessels, extravasation of blood, inflammatory cell infiltration and edematous widening of the intercellular spaces with fibroblasts activation. More support was achieved by the significant increase in the area percent of collagen fibres in this subgroup compared to the control group.

In the chronic stage of MI (subgroup MI-28), histological signs of cell death and inflammatory reaction were diminished with the appearance of well-demarcated areas of fibrosis. These findings were furtherly backed by the significant decrease in the area percent of caspase 3 and the levels of Bax and cardiac enzymes and a significant increase in the area percent of collagen fibres versus subgroup MI-3. Such results are concomitant to those previously reported ${ }^{[34]}$ where they were explained by death and phagocytosis of most of the cells and their replacement by fibrous tissue.

The obvious loss of myocardial cells in subgroup MI-28 unsurprisingly resulted into a significant decrease in HSF1, Hsp70 and miR-34a than subgroup MI-3. Additionally, it was demonstrated that HSF1 and Hsp70 were non-significantly increased than the control with a consequent significant increase in miR-34a. Such increase was certainly accompanied by a significant increase in caspase 3 area percent and levels of Bax and cardiac enzymes in this subgroup compared to the control group.

Chronic stage of MI is associated with marked impairment of the myocardial function ${ }^{[35]}$ which could be explained in this work by the evident loss of cardiac myocytes and the widely spread fibrous tissue disrupting the intercalated discs. Such explanation was backed by the significant decrease in the area percent of connexin 43 in subgroup MI-28 versus MI-3.

In the present work, injection of EXOs, produced by either non-HSBMMSCs or ${ }^{\mathrm{HS}} \mathrm{BMMSCs}$ was followed by their homing at the site of the lesion, 1 day after MI induction, and their absence in the control rats. This could be explained by their attraction to the site of the lesion via interaction between cardiac myocytes' SDF-1 released during lesion and EXOs' CXCR4 ${ }^{[36]}$. This attraction is followed by EXOs internalization inside the lesioned cells through endocytosis, direct fusion or phagocytosis in certain cells ${ }^{[37]}$ transferring their contents to the recipient cells. These contents are variable according to the EXOs' cellular origin $^{[38]}$.

Subgroup MI- ${ }^{\mathrm{nHS}} \mathrm{E}-3$ revealed nearly normal histological architecture as EXOs transported their contents derived from ${ }^{\text {non-HS}}$ BMMSCs to the cardiac myocytes. These contents were shown formerly ${ }^{[1,5,17,21,38]}$ to be anti-apoptotic [B-cell lymphoma 2 (Bcl-2)], anti-inflammatory [interleukin-10 (IL-10)], anti-oxidant [catalase], angiogenic [vascular endothelial growth factor (VEGF)], growth factors [basic fibroblast growth factor and transforming growth factor 
(TGF)- $\alpha$ ], mRNA, microRNA and minimal amount of HSF1. Exosomal HSF1 was assumed to be added to the endogenous one produced by the stressed myocytes resulting in its significant increase versus subgroup MI-3. This exosomal HSF1, after being activated, causes more blockage of miR-34a gene expression than in subgroup MI-3 and consequently, overexpressed Hsp70. Such genetic modification was supported by the significant decrease in miR-34a level and the significant increase in Hsp70 in this subgroup versus subgroup MI-3.

This exosomal preservation was reinforced by the significant decrease in area percent of caspase 3 and collagen fibres in addition to the levels of Bax and cardiac enzymes in this subgroup compared to subgroup MI-3. However, these parameters were still significantly increased than the control group. This finding could be enlightened by that the HSF1 increase was still not adequate to sufficiently block the marked augmentation of miR-34a production. This explanation was defended, in the current study, by the significant increase in miR-34a level in this subgroup compared to the control group.

Such myocardial histological conservation was predictably followed by cardiac functions preservation. This was backed by the significantly increased area percent of connexin 43 in subgroup MI-nHSE-3 versus subgroup MI-3. Nevertheless, the presence of some cardiac myocytes deaths led to disruption of some intercalated discs and consequently the significant decrease in connexin 43 area percent in this subgroup compared to the control group.

Surprisingly 28 days following MI and ${ }^{\text {non-Hs BMMSCs- }}$ EXOs (subgroup $\mathrm{MI}{ }^{-{ }^{\mathrm{nS}}} \mathrm{E}-28$ ), there was a marked deterioration of the histological and functional aspects of the myocardium where it appeared similar to those of the chronic fibrotic stage of MI (subgroup MI-28). This was reinforced by the non-significant differences between the two subgroups regarding different biochemical and morphometric parameters. Further support came from a previous study ${ }^{[39]}$ where there was no difference in the cardiac functions (left ventricular ejection fraction, left ventricular volume and infarct size) between placebo and BMMSCs, in chronic cases of MI.

Such deterioration could be illuminated as SDF-1 derived from the stressed myocytes to attract EXOs is declined to its normal level after 3 days ${ }^{[8]}$. Accordingly, there was no more EXOs at the lesion site and no more trophic factors internalization inside the stressed fibres ${ }^{[21]}$. Successively, there was no more exosomal support to the lesioned cells and the only support was suggested to come from the endogenously released HSF1 which was documented in subgroup MI-3 to be not sufficient to relieve the hypoxic and oxidative stresses. Additionally, the genetic modification produced by the minimal amount of exosomal HSF1 transferred to the stressed cells during the first 3 days was also proved in subgroup MI- ${ }^{\mathrm{nHS}} \mathrm{E}-3$ to be not enough to ameliorate the stresses. Thus, cardiac myocytes started to express the signs of these lesions passing through the acute stage until they reached the chronic fibrotic stage.

Subgroup MI- ${ }^{\mathrm{HS}} \mathrm{E}-3$ revealed apparently normal histological and functional pictures of the myocardium more than in subgroup MI- ${ }^{\mathrm{nHS}} \mathrm{E}-3$. This was supported by the significant decrease in the area percent of caspase 3 and collagen fibres and in the levels of Bax and cardiac enzymes and the significant increase in the area percent of connexin 43 in this subgroup versus subgroup MI- ${ }^{\mathrm{nHS}} \mathrm{E}-3$. Moreover, there were non-significant differences in these statistical results between this subgroup and the control group. More support was obtained from the results of the prior study ${ }^{[17]}$ that stated impressive improvement of the cardiac functions (improved ejection fraction and decreased left ventricular systolic and diastolic dimensions) 1 to 4 weeks following ${ }^{\mathrm{HS}} \mathrm{BMMSCs}$ injection in cases of MI.

Such better preservation compared to subgroup MI- ${ }^{\mathrm{nHS}} \mathrm{E}-3$ could be explained by the large amount of HSF1 translocated from ${ }^{\mathrm{HS}} \mathrm{BMMSC}$ to the recipient cardiac cells via EXOs. As EXOs' contents varied according to the environmental stimuli to which parent cells are subjected ${ }^{[40]}$. This explanation was supported by an earlier in vitro study ${ }^{[17]}$ where ${ }^{\mathrm{HS}} \mathrm{BMMSCs}$ was proved to produce much more HSF1 in their cytoplasm than ${ }^{n o n-H S}$ BMMSCs. This clarification was furtherly supported in the current work by the significant increase in ${ }^{\mathrm{HS}} \mathrm{F} 1$ level in ${ }^{\mathrm{HS}} \mathrm{BMMSCs-EXOs}$ than ${ }^{n-\mathrm{H}} \mathrm{HS}$ BMMSCs-EXOs and in this subgroup compared with subgroup $M I-{ }^{n H S} E-3$. High level of EXOs' HSF1 was suggested to trigger much more genetic modification in myocardial cells with consequent sufficient decrease in miR-34a level (significantly decreased than MI- ${ }^{\mathrm{nH}}$ SE-3 and not significantly increased than the control) and appropriate increase in Hsp70 level (significantly increased than both subgroup MI- ${ }^{\mathrm{nH}}$ SE-3 and the control group).

Although ${ }^{\mathrm{HS}} \mathrm{BMMSCs-EXOs}$ were no more attracted to the lesion site after 3 days, they efficiently continued to support the myocardium 28 days after MI (subgroup $\left.\mathrm{MI}-{ }^{\mathrm{HS}} \mathrm{E}-28\right)$. This finding was reinforced by the non-significant difference in the area percent of caspase 3 , collagen fibres and connexin 43 and in the levels of Bax and cardiac enzymes in this subgroup versus both subgroup $\mathrm{MI}-{ }^{\mathrm{HS}} \mathrm{E}-3$ and control group. Similar results were documented previously ${ }^{[17]}$ following ${ }^{\mathrm{HS}} \mathrm{BMMSCs}$ transplantation to the hearts with MI for 28 days.

This sustained support could be elucidated by the persistence of the genetic modification induced by the prominent exosomal HSF1 transported to the myocardial cells in the first 3 days. This, in turn, resulted into the significant decrease in miR-34a level and the significant increase in HSF1 and Hsp70 levels in this subgroup versus subgroup MI- ${ }^{\mathrm{nH}} \mathrm{SE}-28$ in addition to the non-significant increase in miR-34a level and the significant increase in HSF1 and Hsp70 levels versus the control group.

It could be concluded that both ${ }^{\text {non-HS}}$ BMMSCs-EXOs and ${ }^{\mathrm{HS}} \mathrm{BMMSCs}-\mathrm{EXOs}$ were effective in the conservation of the biochemical, histological and functional aspects 
of the left ventricular myocardium in the early stage of MI, which was more obvious with ${ }^{\mathrm{HS}} \mathrm{BMMSCs-EXOs.}$ However, in the chronic stage of MI ${ }^{n o n-H S} B M M S C s-$ EXOs had a non-therapeutic effect on the myocardium, in contrast to the marked curative and conservative effects of ${ }^{H S}$ BMMSCs-EXOs. Such flawless preservation was shown to be due to the ability of ${ }^{\mathrm{HS}} \mathrm{BMMSCs-EXOs} \mathrm{to} \mathrm{manipulate}$ and change the gene expression and the subsequent protein production by the myocardial cells via their high level of HSF1.

\section{CONFLICT OF INTERESTS}

There are no conflicts of interest.

\section{REFERENCES}

1. Zhao Y, Sun X, Cao W, Ma J, Sun L, Qian H, Zhu $\mathrm{W}$ and $\mathrm{Xu} \mathrm{W}$. Exosomes Derived from Human Umbilical Cord Mesenchymal Stem Cells Relieve Acute Myocardial Ischemic Injury. Stem Cells International (2015) 2015:761643-761655

2. Global, regional, and national incidence, preva $\neg$ lence, and years lived with disability for 328 diseases and injuries for 195 countries, 1990 2016: A systematic analysis for the Global Burden of Disease Study 2016. GBD 2016 Disease and Injury Incidence and Prevalence Collaborators. Lancet (2017) 390(10100): 12111259

3. Varghese T, Hayek SS, Shekiladze N, Schultz WM and Wenger NK. Psychosocial risk factors related to ischemic heart disease in women. Curr Pharm Des (2016) 22(999): 38533870

4. Ptaszek LM, Mansour M, Ruskin JN and Chien KR. Towards regenerative therapy for cardiac disease. Lancet (2012) 379(9819):933-942

5. Ferreira JR, Teixeira GQ, Santos SG, Barbosa MA, Almeida-Porada $G$ and Gonçalves RM. Mesenchymal Stromal Cell Secretome: Influencing Therapeutic Potential by Cellular Pre-conditioning. Front. Immunol (2018) 9:2837

6. Rowart P, Erpicum P, Detry O, Weekers L, Gregoire C, Lechanteur C, Briquet A, Beguin Y, Krzesinski JM and Jouret F. Mesenchymal stromal cell therapy in ischemia/reperfusion injury. J Immunol Res (2015) 2015: 602597

7. Wu KH, Mo XM, Han ZC and Zhou B. Stem cell engraftment and survival in the ischemic heart. Ann Thorac Surg (2011) 92(5):1917-1925

8. Mayorga ME, Kiedrowski M, McCallinhart P, Forudi F, Ockunzzi J, Weber K, Chilian W, Penn MS and Dong F. Role of SDF-1:CXCR4 in impaired post-myocardial infarction cardiac repair in diabetes. Stem Cells Transl Med (2018) 7(1):115-24
9. Vizoso FJ, Eiro N, Cid S, Schneider $\mathrm{J}$ and Perez-Fernandez R. Mesenchymal stem cell secretome: toward cell-free therapeutic strategies in regenerative medicine. Int J Mol Sci (2017) 18(9):1852-1914

10. Caplan AI and Dennis JE. Mesenchymal stem cells as trophic mediators. J Cell Biochem (2006) 98(5): 1076-84

11. Yáñez-Mó M, Siljander PR, Andreu Z, Zavec AB, Borràs FE, Buzas EI, Buzas K, Casal E, Cappello $\mathrm{F}$, et. al, Biological properties of extracellular vesicles and their physiological functions. J Extracell Vesicles (2015) 4:27066

12. Simpson RJ, Jensen SS and Lim JWE. Proteomic profiling of exosomes: current perspectives. Proteomics (2008) 8(19):4083-4099

13. Dougherty JA, Mergaye M, Kumar N, Chen CA, Angelos MG and Khan M. Potential role of exosomes in mending a broken heart: nanoshuttles propelling future clinical therapeutics forward. Stem Cells Int (2017) 2017:5785436

14. Moloney TC, Hoban DB, Barry FP, Howard L and Dowd E. Kinetics of thermally induced heat shock protein 27 and 70 expression by bone marrow-derived mesenchymal stem cells. Protein Sci (2012) 21(6): 904-9

15. Santos-Junior VA, Lollo PCB, Cantero MA, Moura CS, Amaya-Farfan J and Morato PN. Heat Shock Proteins: Protection and Potential Biomarkers for Ischemic Injury of Cardiomyocytes after Surgery. Braz J Cardiovasc Surg (2018) 33(3):291-302

16. Li Q, Shi M and Li B. Anandamide enhances expression of heat shock protein 72 to protect against ischemia-reperfusion injury in rat heart. J Physiol Sci (2013) 63(1):47-53

17. Feng Y, Huang W, Meng W, Jegga AG, Wang Y, Cai W, Kim HW, Wen Z, Rao F, Modi RM, $\mathrm{Yu} \mathrm{X}$ and Ashraf M. Heat Shock Improves Sca-1+ Stem Cells Survival and Directs Ischemic Cardiomyocytes towards a Prosurvival Phenotype via Exosomal Transfer: a Critical Role for HSF $1 / \mathrm{miR}-34 \mathrm{a} / \mathrm{HSP} 70$. Stem Cells (2014) 32(2): 462-472

18. Leonardo A. M. Zornoff, Sergio A. R. Paiva, Marcos F. Minicucci and Joel Spadaro. Experimental Myocardium Infarction in Rats: Analysis of the Model. Arq Bras Cardiol (2009) 93(4): 403-408

19. Li N, Yang YJ, Qian HY, Li Q, Zhang Q, Li XD, Dong QT, Xu H, Song $\mathrm{L}$ and Zhang $H$. Intravenous administration of atorvastatin-pretreated mesenchymal stem 
cells improves cardiac performance after acute myocardial infarction: role of CXCR4. Am J Transl Res (2015)7(6):1058-1070

20. Thery C, Amigorena S, Raposo G and Clayton A. Isolation and characterization of exosomes from cell culture supernatants and biological fluids. Curr Protoc Cell Biol (2006) 3(3):22

21. Huang P, Wang L, Li Q, Xu J, Xu J, Xiong Y, Chen G, Qian H, Jin C, Yu Y, Liu J, Qian L and Yang Y. Combinatorial treatment of acute myocardial infarction using stem cells and their derived exosomes resulted in improved heart performance. Stem Cell Research \& Therapy (2019) 10(1):300

22. Tawfik MK and Ameen AM. Cardioprotective effect of ranolazine in nondiabetic and diabetic male rats subjected to isoprenaline-induced acute myocardial infarction involves modulation of AMPK and inhibition of apoptosis. Canadian Journal of Physiology and Pharmacology (2019)97(7):661-674

23. El-Akabawy G and El-Kholy W. Neuroprotective effect of ginger in the brain of streprozotocin-induced diabetic rats. Ann Anat (2014) 196(2-3): 119- 128

24. El Agaty SM. Cardioprotective effect of vitamin D2 on isoproterenol-induced myocardial infarction in diabetic rats. Archives of Physiology and Biochemistry (2019) 125(3):210-219

25. Kiernan JA. Histological and histochemical methods: Theory and practice. $5^{\text {th }}$ ed, Scion Publishing, Banbury, UK (2015) pp. 111-162

26. Suvarna K and Layton C, Bancroft J. Connective and mesenchymal tissue with their stains. Immunohistochemical techniques In: Bancroft's Theory and practice of Histological Techniques, 7th ed, Churchill Livingstone Elsevier, Oxford. (2013) pp. 187-214, 381-426

27. Emsley R, Dunn G and White IR. Mediation and moderation of treatment effects in randomised controlled trials of complex interventions. Stat Methods Med Res (2010) 19(3): 237-270

28. Menazza S and Murphy E. The expanding complexity of estrogen receptor signaling in the cardiovascular system. Circ Res (2016) 118(6): 994-1007

29. Konstantinidis K, Whelan RS and Kitsis RN. Mechanisms of Cell Death in Heart Disease Arterioscler Thromb Vasc Biol (2012) 32(7): 1552-1562
30. Zhang J, Biggar KK and Storey KB. Regulation of p53 by reversible posttranscriptional and post-transcriptional mechanisms in liver and skeletal muscle of an anorexia tolerant turtle, trachemys scripta elegans. Gene (2013) 513(1)3:147-155

31. Beyfuss K and Hood DA. A systematic review of $\mathrm{p} 53$ regulation of oxidative stress in skeletal muscle. Redox Rep (2018) 23(1):100-117

32. Metias EF, Aboelmaaty NM, Hussein AM, Abdallah EW and Abdelaziz A. Modulation of ECG, Myocardial Oxidative Stress Markers and Connexion 43 Expression by Ascorbic Acid and Ferulic Acid in Isoproterenol-Induced Myocardial Infarction in Rats. Biochem Physiol (2016) 5: 210

33. Yu X, Deng L, Wang D, Li N, Chen X, Cheng X, Yuan J, Gao X, Liao M, Wang M and Liao Y. Mechanism of TNF $\alpha$ autocrine effects in hypoxic cardiomyocytes: Initiated by hypoxia-inducible factor $1 \alpha$, presented by exosomes. J. Mol. Cell. Cardiol (2012) 53(6): 848-857

34. Chistiakov DA, Orekhov AN and Bobryshev YV. Cardiac Extracellular Vesicles in Normal and Infarcted Heart Int. J Mol Sci (2016) 17(1): 63

35. Miki K, Uenaka H, Saito A, Miyagawa S, Sakaguchi T, Higuchi T, Shimizu T, Okano T, Yamanaka S and Sawa Y. Bioengineered Myocardium Derived from Induced Pluripotent Stem Cells Improves Cardiac Function and Attenuates Cardiac Remodeling Following Chronic Myocardial Infarction in Rats Stem Cells Translational Medicine (2012) 1(15):430-437

36. Ciullo A, Biemmi V, Milano G, Bolis S, Cervio E, Fertig ET, Gherghiceanu M, Moccetti T, Camici GG, Vassalli G and Barile L. Exosomal Expression of CXCR4 Targets Cardioprotective Vesicles to Myocardial Infarction and Improves Outcome after Systemic Administration. Int J Mol Sci (2019) 20(3): 468-505

37. Mulcahy LA, Pink RC and Carter DR. Routes and mechanisms of extracellular vesicle uptake. J Extracell Vesicles (2014) 3:24641

38. Camussi G, Deregibus MC, Bruno S, Cantaluppi $\mathrm{V}$ and Biancone L. Exosomes/microvesicles as a mechanism of cell-to-cell communication. Kidney Int (2010) 78(9):838-48

39. Traverse JH, Henry TD, Pepine CJ, Willerson JT, Chugh A, Yang PC, Zhao DXM, Ellis SG, Forder JR, Perin EC, Penn MS, Hatzopoulos AK, Chambers JC, Baran KW, Raveendran G, Gee AP, 
Taylor DA, Moyé L, Ebert RF and Simari RD. The TIME Trial - Effect of Timing of Stem Cell Delivery Following ST-Elevation Myocardial Infarction on the Recovery of Global and Regional Left Ventricular Function: Final 2-Year Analysis. Circ Res (2018) 122(3): 479-488
40. Zhu J, Lu K, Zhang N, Zhao Y, Ma Q, Shen J, Lin Y, Xiang P, Tang Y, Hu X, Chen J, Zhu W, Webster $\mathrm{KA}$, Wang $\mathrm{J}$ and $\mathrm{Yu} \mathrm{H}$. Myocardial reparative functions of exosomes from mesenchymal stem cells are enhanced by hypoxia treatment of the cells via transferring microRNA-210 in an nSMase2dependent way. Artif Cells Nanomed Biotechnol (2018) 46(8):1659-1670 


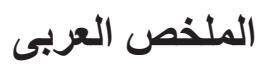

التأثير العلاجي للإكسوسومات المستمدة من الخلايا الجذعية الغير معرضة للصدمة الحرارية مقابل المعرضة للصدمة الحرارية على احتشاء عضلة القلب المحدث تجريبيا في مئه ذكور الجرذان البيضاء البالغين

مروة محمد يسرى وعبير ابراهيم عمر

قسم علم الانسجة_كلية الطب-جامعة القاهرة

المقدمة: يعتبر احتشاء عضلة القلب (MI) في جميع أنحاء العالم سببا رئيسيا للوفيات، حيث يؤدي إلى موت عضلة القلب وضعف وظائف القلب. إن إكسوسومات الخلايا الجذعية الوسيطة للنخاع العظمي (BMMSCs)هي عبارة عن حويصلات خارجة من الخلايا، نانوية الحجم ولها نفس الإمكانيات التعويضية للخلايا الجذعية. وتعتبر الصدمة الحر ارية و احدة من الضغوط التي تزيد من إنتاج بروتينات الصدمة الحر ارية في الخلايا الجذعية مما يزيد من قدر اتها على البقاء. الهدف من العمل: تهدف الدر اسة الحالية إلى تقييم ومقارنة الإمكانات العلاجية للإكسوسومات المستمدة من BMMSCs الغير معرضة للصدمة الحر ارية و المعرضة للصدمة الحرارية (non-HSBMMSCs-EXOs \&

على احتثاء عضلة القلب المحدثة تجريبيا (المر احل الحادة و المزمنة) مع توضيح التفسير المحتمل لهذا الاختلاف. المواد وطرق البحث: تم تقسيم سته وخمسون من ذكور الجرذان البيضاء البالغين إلى المجموعة الواهبة (لإعداد

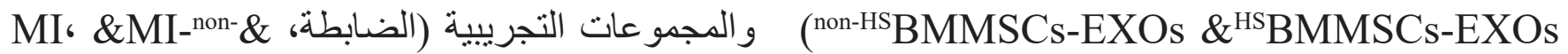
HSBMMSs-EXOs، \&MI-HSBMMSCs-EXOs وجرذين من كلا من المجموعتين MIلتأكيد وصول BMMSCs-EXOs MI المصلية و الكيميائية و النسيجية و القياسات المترية الشكلية. النتائج: اظهرت المرحلة الحادة من احتشاء عضلة القلب تحلل الخلايا وملامح التهابية بينما أظهرت المرحلة المزمنة تغير ات ليفية ملحوظة. وقد تر اجعت هذه التغييرات في مجمو عات MI-

MX باستثناء تلك التي تنتمى لمجمو عة MOnHSBMMSCs-EXOs وتم التضحية بجرذانها بعد 28 يومًا. الاستنتاج: كان لكلا من HSBMMSCs-EXOs و قدر بات علاجية في المرحلة الحادة

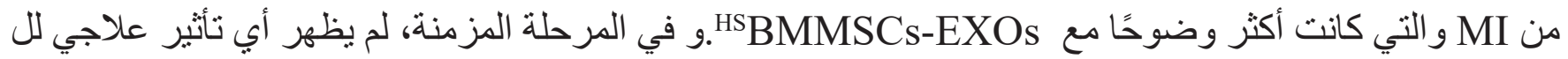
nonHSBMMSCs-EXOs على الرغم من التأثير المثالي لل HSBMSCs-EXOs. 